\title{
Development and validation of clinical cases to be used in maternal-child nursing education
}

Construção e validação de casos clínicos para utilização no ensino de enfermagem no contexto materno-infantil

Construcción y validación de casos clínicos para usarlos en la enseñanza de enfermería en el contexto materno-infantil

Casandra G. R. M. Ponce de Leon*(D); Ana Karolina Silva**; Laiane Medeiros Ribeiro*** (D);

Guilherme da Costa Brasil ${ }^{* * * *}$ (D); Laise Escalianti del Alamo Guarda*****(D); Luciana Mara Monti Fonseca ${ }^{* * * * * *}$ (D)

\section{Abstract}

Background: As an active teaching method, simulation allows improving cognitive and rational skills, critical judgment, teamwork, task division, and leadership.

Objective: To describe the development of 2 clinical cases and validate them to be used in high-fidelity maternal-child simulation.

Methodology: A two-phase methodological validation study was conducted. The first phase consisted of the identification of the school's health care needs and the development of 2 clinical cases to be used in high-fidelity maternal-child simulation. The second phase consisted of the validation of the cases and instruments for assessment of simulation in the training process. Results: The experts assessed the items using the Content Validity Index (CVI). The suggestions aimed at improving the scenario assessment tools and contributed to the reliability of the developed clinical cases.

Conclusion: The validation of the scenarios by the experts reflected the adequacy of the items in the instruments and promoted another implementation of the cases designed for high-fidelity maternal-child simulation.

Keywords: teaching; simulation; validation studies; nursing; pediatrics

\section{Resumo}

Enquadramento: A simulação, como um método ativo de ensino, permite o estímulo da capacidade cognitiva, racional, visão crítica e exercício do trabalho em equipa, divisão de tarefas e liderança.

Objetivo: Descrever a construção de 2 casos clínicos e validá-los para utilização na simulação realística materno-infantil. Metodologia: Estudo de validação do tipo metodológico, realizado em duas fases. Na primeira fase, realizou-se o levantamento das necessidades de cuidados em saúde escolar e elaboração de 2 casos clínicos para utilizar em simulação realística materno-infantil. $\mathrm{Na}$ segunda fase, procedeu-se à validaçáo dos casos e dos instrumentos elaborados para avaliação da simulação no processo de formação.

Resultados: Os juízes avaliaram os itens que foram analisados através do Índice de Validade de Conteúdo (IVC). As sugestôes foram apontadas para melhorar os instrumentos de avaliaçáo dos cenários e houve a contribuição para a fidedignidade dos casos clínicos construídos.

Conclusáo: A validação dos cenários pelos juízes viabilizou a adequação de itens nos instrumentos favorecendo uma nova implementação dos casos elaborados para a simulação realística materno-infantil.

Palavras-chave: ensino; simulação; estudos de validação; enfermagem; pediatria

*MSc., Professor, University of Brasilia, Faculty of Ceilândia, 72220-900, Ceilândia, Brasil [casandrapleon@omail com (10 https:/Orcid.org/0000-0003-4378-9200.Contribution to the article: data ana sis and discussion, statistical treatment and evaluation, article revision. Address for correspondence. Av. Araucárias, lote 4530, bloco E, apto. 2501, Sul - Aquas Claras. CEP: 71.936-250. Braslilia Brasil. **Bacharelaro, Student, University of Braślia, Faculty of Ceilândia, 72220-900, Ceilândia, Brasil [anakarolina silva24@outlook.com].Contribution to the article: literature search, participation in experimentation and data collection.

***:Ph.D., Nurse, University of Brasilia Faculty of Ceilândia, 72220-900, Ceilândia Brasil [lainha(@ gmail.coml. (Dhttp://orcid org/0000-0002-5041-8283. Contribution to the article: statistical tre ment and evaluation and data analysis.

***:* MSc, Nurse, University of Brasilia, Faculty of Ceilândia 72220-900, Ceilândia Brasil [o lhermecostabrasil@ hotmail.com].๑ https://orcid.org/0000-0001-6878-7098. Contribuição no artigo: data analysis and discussion

*****MSc. Nurse, University of Brasilia, Faculty of Ceilândia 72220-900 Ceilândia Brasil [la seescalianti@hotmail.com].0 https://orcid.org/0000-0002-2084-0117. Contribution to the

*article: data analysis and discussion. 902, Ribeirão Preto, Brasil llumonti@ eerp.usp.br].@ https://orcid.org/0000-0002-5831-8789. Contribution to the article: data analysis and discussion.

\section{Resumen}

Marco contextual: La simulación, como método activo de enseñanza, permite estimular la capacidad cognitiva, la racional, la visión crítica y el ejercicio del trabajo en equipo, la división de tareas y el liderazgo.

Objetivo: Describir la construcción de 2 casos clínicos y validarlos para su uso en la simulación realista materno-infantil.

Metodología: Estudio de validación de tipo metodológico, realizado en dos fases. En la primera fase, se realizó la recopilación de las necesidades de atención en salud escolar y la elaboración de 2 casos clínicos para utilizarlos en la simulación realista materno-infantil. En la segunda fase se procedió a la validación de los casos y de los instrumentos elaborados para evaluar la simulación en el proceso de formación.

Resultados: Los jueces evaluaron los ítems que se analizaron a través del Índice de Validez de Contenido (IVC). Se apuntaron las sugerencias para mejorar los instrumentos de evaluación de los escenarios y hubo una contribución a la fidedignidad de los casos clínicos construidos.

Conclusión: La validación de los escenarios por los jueces viabilizó la adecuación de los ítems en los instrumentos, lo que favoreció una nueva implementación de los casos elaborados para la simulación realista materno-infantil.

Palabras clave: enseńanza; simulación; estudios de validación; enfermería; pediatría 


\section{Introduction}

Over time, society's health needs have grown and nursing education has evolved to better educate the future professionals to meet the demands of society. One of these advances is high-fidelity simulation, which is a way of effectively achieving the teaching-learning ability.

As an active teaching method, simulation allows improving cognitive and rational skills, critical judgment, teamwork, task division, and leadership. Studies have revealed students' satisfaction with the training of skills using simulators because they feel motivated by being at the center of the process and increase their competence through simulated scenarios (Fernandes et al., 2016; Negri et al., 2017; Souza et al., 2017).

Several scenarios can be developed to bring students closer to real life and improve student learning. In these scenarios, students can improve their self-confidence by learning from their errors in a simulated environment where their doubts are not harmful to the patients' health. Thus, students can improve their nursing techniques to better reproduce them in a real context.

However, although there are several simulated cases in various areas of knowledge available in the literature, there is still little evidence on their validation. In medicine, there have been reports of simulator validation in anesthesia errors (Merry et al., 2017) and in cases of stent-graft deployment (Perrin et al., 2015). In nursing, reports were found on the validation of a questionnaire on students' satisfaction with simulation for the Spanish and Portuguese languages (Alconero-Camarero, Gualdrón-Romero, Sarabia-Cobo, \& Martinez-Arce, 2016; Almeida et al., 2015) and on perinatal emergencies in high-fidelity simulation (Balki et al., 2017). A study was found on the personal satisfaction and gains of nursing students who used high-fidelity simulation in their educational experiences (Baptista, Martins, Pereira, \& Mazzo, 2014).

The number of publications on the effectiveness of high-fidelity simulation in education has increased over time. Despite this, there are only a few references on the development and validation of clinical cases for maternal-in- fant simulation (Góes, Dalri, Fonseca, Canini, \& Scochi, 2014). The authors found no studies on the validation of clinical cases that addressed the interdisciplinary of the maternal-child areas.

In view of the above, the objective of this study was to describe the development and validation of two clinical cases for further use in high-fidelity maternal-child simulation.

\section{Background}

Students often lack the opportunity to experience the subjects taught in theory and discussed in the classroom as well as in the different venues of practical traineeship during their programmes. Simulated scenarios are a major help because this active method will enable them to experience different situations, encouraging the clinical reasoning between the theoretical and practical contents (Carvalho, Oliveira-Kumakura, \& Morais, 2017).

An excellent education during the undergraduate programmes is reflected in the health job market because professionals will be better prepared and act as innovative and transforming agents who increase the satisfaction of their patients, thus strengthening the health system and the quality of the care provided to the community.

In a study with the purpose of describing the implementation of simulation-based education within a nursing education programme, the sampled 27 students reported that this experience was very positive. They highlighted the importance of teamwork and communication; the principles of airway, breathing, and circulation; and to take a full patient history. Some of them also mentioned the important role that nurses played in assessing a patient; hand hygiene; availability of proper equipment; documenting the nursing care; and caring for relatives in an acute situation (Tjoflat, Vaga, \& Soreide, 2017).

Students explained that the simulation scenarios seemed to be a "real situation" and that it facilitated the delivery of proper care. One student said that "Simulation increases our capacity to learn because it is done by acting out real situations in caring for the patients" (Tjoflat et al., 2017, p. 2). 
In Brazil, a cross-sectional study with undergraduate nursing students aimed to assess the use of clinical simulation in pediatrics. The participants in this study reported that the topics discussed during the simulation were considered important and that the duration of the simulation was adequate. They agreed that the simulation activity allowed them to put into practice the theoretical contents taught by the teachers in the classroom and that simulation can be introduced into the subject as a methodological strategy to promote students' self-confidence (Fernandes et al., 2016).

A recent systematic review aimed to assess whether the existing simulation programs help to prevent medication errors. Twenty-one studies assessed simulation-based learning programs, focusing on pharmacy, medicine, and nursing students, or programs aimed at reducing administration or preparation errors, managing crises, or learning communication skills for healthcare professionals (Sarfati et al., 2018).

The studies varied in design, methodology, and assessment. Few have demonstrated that simulation was more effective than didactic learning in reducing medication errors. This review highlights the lack of long-term assessment, with limited scenarios and participant samples. These various experiences, however, help in identifying the key elements required for an effective human simulation-based learning program for the prevention of medication errors (Sarfati et al., 2018).

Regardless of the area where simulation will be used, it is important to plan every step of the simulation process, such as the development of cases by the teachers or professionals, the identification of the material to be used, the organization of simulated scenarios and their presentation to the target audience, and debriefing, always considering the duration of the scenarios and the skills and competencies to be developed in each simulated activity.

\section{Research question}

What is the process of development and validation of clinical cases with the purpose of creating procedures for high-fidelity maternal-child simulation?

\section{Methodology}

This validation study for methodological development was conducted in two phases: the development of the scenarios and the validation of the simulation tools by experts in the health area.

It refers to the research on methods for obtaining and organizing data and conducting accurate studies. It is a study on the development, validation, and assessment of research tools and methods (Polit \& Beck, 2011).

First, the report from the 2015 National Survey of School Health in Brazil (PeNSE; latest report made available by the Brazilian Ministry of Health and Ministry of Education) was analyzed. In this report, the major problems affecting the students' lives (aged 13 to 17 years) were identified (Instituto Brasileiro de Geografia e Estatística, 2016). Based on this analysis, the following two clinical cases were developed: Clinical Case 1 - Adolescents' use of licit and illicit drugs and sexual abuse of a minor; and Clinical case 2 - Early sexual initiation, pregnancy, and abortion among adolescents. 

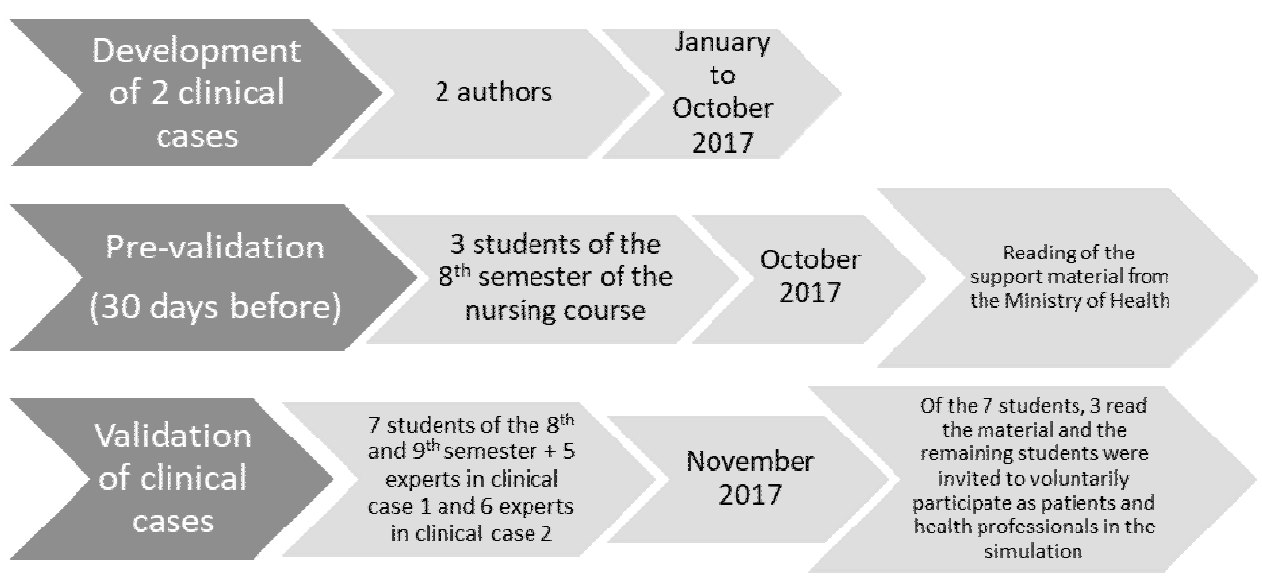

Figure 1. Research steps.

The scenario of clinical case 1 aimed to identify students' clinical, affective, and cognitive skills in order to deliver safe patient care.

The scenario of clinical case 2 aimed to assess the clinical, cognitive, and affective skills that could facilitate the patient's decision-making and preparation for self-care.

Checklists (simulation assessment forms) were built to guide the voluntary students. Clinical case 1 and 2 were validated by five and six experts, respectively, who had to assess the organization, comprehensiveness, objectivity, and adequacy of each element and the instruments used in the scenario. All of them gave their consent by signing an Informed Consent Form.

The experts were selected based on the scoring system for expert selection adapted by Góes et al. (2014). The minimum score in this study was 4 points. With regard to the titles hold, only 1 point was computed, even if the expert held more than one title in their training experience. The scoring for expert selection in clinical case 1 ranged from 7 to 9 points, with $80 \%$ of the experts having experience with high-fidelity simulation. These experts' mean age was 30.2 years. In clinical case 2, the score also ranged from 7 to 9 points and $66.7 \%$ of the experts had experience with simulation. Their mean age was 30.8 years. The instrument for expert characterization analyzed their titles (Ph.D., Master or Specialization), main area of activity (hospital, health care, education), experience with teaching and simulation, developed or supervised research, and publications on topics related to the validation of simulated scenarios.

Thus, in both maternal-child simulation scenarios, it should be emphasized that all experts were nurses. In clinical case 1, one of the experts had a Nursing Ph.D., one had a Master's in Nursing, and three had the title of nursing specialists (in the areas of neonatology/pediatrics, maternal-child health). In clinical case 2 , one of the experts had a Nursing Ph.D., one had a Master's in Nursing, and four had the title of specialists (in the areas of neonatology/pediatrics, maternal-child health, and pediatric emergency). In clinical case 1 , four experts were women and one was a man, while in clinical case 2 all of the experts were women. The characterization tool did not assess their marital status or whether they had children. All of them reported having teaching experience.

Two instruments were used for planning the simulation validation process: a questionnaire for expert characterization and the high-fidelity scenario validation tool.

The experts analyzed 20 items which covered general aspects of the scenario, such as the students' performance in this clinical scenario, and were classified as follows: inappropriate, partly inappropriate, and appropriate. Nine other items on the objectives to be achieved by the participants in the scenarios were also assessed and rated as follows: adequately performed within the established time limit, adequately performed but not within the established time limit, inadequately performed, and not performed. The instrument also included a box for subjective observations about the simulation. 
Subsequently, the content validity index (CVI) was used to check for inter-rater agreement about keeping or not keeping the items on the checklist for each case (first instrument) and the assessment of the simulation objectives (second instrument).

To calculate the instruments' overall CVI, the CVIs which were calculated separately were summed and divided by the number of items in each instrument (20 items in the first instrument and nine items in the second instrument; Góes et al., 2014). The minimum index of 0.75 was considered acceptable for both the assessment of each item and the overall assessment of both instruments (Alexandre \& Coluci, 2011; Medeiros et al., 2015).
The study complied with the formal requirements in the national and international guidelines for research involving human beings. It was approved in Brazil by the Research Ethics Committee under CAAE No. 55504716.7.0000.0030.

\section{Results}

The model in Tables 1 and 2 was based on the study of Eduardo, Mendes, Binotto, Tognolli, and Tucci (2016). It describes the planning of each clinical case, which can be implemented in high-fidelity maternal-child simulation in the future.

\section{Table 1}

\section{Summary of the elements of the scenario of clinical case 1}

Scenario of clinical case 1: Adolescents' use of licit and illicit drugs and sexual abuse of a minor

Learning objective

\begin{tabular}{ll}
\hline Duration & 10 minutes \\
\hline Participants & Two nursing undergraduate students \\
\hline Simulator & $\begin{array}{l}\text { Hybrid simulation: people (actors/patients) and virtual reality (computer graphics } \\
\text { connected to controllable devices). }\end{array}$ \\
\hline
\end{tabular}

Hospital bed, heart rate monitor, telephone, room divider, non-sterile gloves, tray, stethoscope, thermometer, flashlight, tongue depressor, non-sterile gauze sponges, $70 \%$ alcohol, nasal oxygen catheter Ambu bag-valve-mask, thermal blanket, nee-

Materials dles, 3-liter sharps containers, standard macrodip set, 3-way system to administer medication, surgical tape, emergency vehicle with three drawers, endotracheal tube, defibrillator, gel, $0.9 \%$ saline, distilled water, medication (for example, diazepam and emergency contraception).

Prerequisites to participate

Nursing students who attended the subject of Women and Child's Integral Health Care (or subject with an equivalent content).

13-year-old Amanda and 15-year-old Roberta were admitted to the emergency room of a pediatric hospital in the neighborhood where they live on 15 June at 6.30 a.m. The nurses asked them where they had been prior to hospital admission and Roberta answered that they had attended a June Festival (Festa Junina) organized by their church and that after it Amanda had slept at her house. When they got there, Roberta said that her friend was behaving strangely, grinding her teeth, her eyes were wide open, anxious, with blurred vision, with a burning and itching sensation

Clinical case while urinating, and an episode of vomiting. In Amanda's physical examination, the nurse failed to perform an anamnesis because the adolescent was constrained and scared. Vital signs: tachycardia $(130 \mathrm{bpm})$, hyperthermia $\left(39.8^{\circ} \mathrm{C}\right)$, tachypnea $(23$ $\mathrm{rpm})$, and hypertension $(140 \times 80 \mathrm{mmHg})$. The adolescent had diaphoresis, tremors, and defensive behavior when the professional touched her body to perform the physical examination. The patient was at the pediatric emergency room waiting for assistance. At patient admission, the physician requested all of the relevant examinations for the clinical case. Patient's weight: $50 \mathrm{Kg}$. 
Table 2

Summary of the elements of the scenario of clinical case 2

\begin{tabular}{ll} 
Scenario clinical case 2: early sexual initiation, pregnancy, and abortion. \\
\hline Learning objective & $\begin{array}{l}\text { To deliver humanized care to the adolescent and demonstrate clinical and cognitive } \\
\text { skills to facilitate the patient's decision-making process and preparation for self-care. }\end{array}$ \\
\hline Duration & 10 minutes \\
\hline Participants & One nursing undergraduate student \\
\hline Simulator & People (actors/patients) \\
\hline Materials & $\begin{array}{l}\text { Stethoscope, sphygmomanometer, thermometer, flashlight, rapid screening tests for } \\
\text { syphilis, HIV, and pregnancy, } 70 \% \text { alcohol, and gauze sponge. }\end{array}$ \\
\hline Prerequisites to participate & \begin{tabular}{l} 
Students who had attended the subject of Women and Child's Integral Health Care. \\
\hline
\end{tabular} \\
Clinical Case & $\begin{array}{l}\text { Maria Júlia, female, } 16 \text { years, attended the basic health unit (family health unit, in } \\
\text { European Portuguese) with a report of moderate pain in the lower abdomen, amen- } \\
\text { orrhea for the past } 2 \text { months, and does not know if she is pregnant. The patient is } \\
\text { feeling very anxious and distressed and reported having searched online for abortion } \\
\text { teas and other unknown recipes mixing teas with alcoholic drinks. She wants to ter- } \\
\text { minate her pregnancy if the result of the pregnancy test is positive. The unit's nurse } \\
\text { performs the pregnancy test and the result is positive. Physical examination: HR: } 90 \\
\text { bpm; RR: } 22 \text { rpm; Temperature: } 36.5^{\circ} \text { C; BP: } 140 x 80 \text { mmHg. }\end{array}$
\end{tabular}

To meet the objective of this study, the simulation activity was conducted with nursing students and the instruments planned for each case were assessed by the invited experts. Thus, each clinical case will have 5 minutes for briefing (presentation of the problem, simulation objectives, scenario and materials for the practical procedure) and 10 to 12 minutes for simulated practice in each clinical case.

The debriefing lasted approximately 25 minutes for clinical case 1 and approximately 35 minutes for clinical case 2 . This step followed a pre-established five-step script, where students reflected about the following aspects: emotional (about how they felt); descriptive (about the scenario experienced); evaluative (students highlighted the positive aspects); analytical (students were encouraged to talk and think about what they could have done differently), and conclusive (decision making and teamwork) in a bilateral conversation with the teacher and experts in maternal-child health. The elements of the scenarios were validated based on the criteria shown in Table 3, which presents the numerical results obtained from the calculation of the CVI of the items assessed in each clinical case. The model shown in Table 3 was based on work by Medeiros et al. (2015) and adapted for this study with the authors' permission.

Based on CVI data, in clinical case 1, six items were below 0.75 , that is, below the criterion of decision on acceptance. Criteria 1, 13, 15, 17, and 18 had blank votes that were not counted. The experts gave some suggestions for the instrument, such as: "It would be interesting if some of the items assessed the professionals' verbal and non-verbal communication with the patients" (Expert 3, September 2017).

In clinical case 2 , six items were below the acceptance criterion. Only item 18 obtained a blank vote. The experts gave suggestions for the clinical case, such as the deletion of some unnecessary items from their point of view (do not "perform the pelvic exam" because it is the first contact with the patient and materials that would be used in this activity) and the inclusion of some materials. 
Table 3

Experts' assessment of the items of the instrument about each clinical case

CLINICAL CASE 1 (Adolescents' use of licit and illicit drugs and sexual abuse of a minor)

\begin{tabular}{|c|c|c|c|c|c|c|c|}
\hline \multirow[b]{2}{*}{ Assessed items } & \multicolumn{2}{|c|}{ Inappropriate } & \multicolumn{2}{|c|}{ Partially appropriate } & \multicolumn{2}{|c|}{ Appropriate } & \multirow[b]{2}{*}{ CVI } \\
\hline & $\begin{array}{l}\text { No. of } \\
\text { experts }\end{array}$ & $\%$ & $\begin{array}{l}\text { No. of } \\
\text { experts }\end{array}$ & $\%$ & $\begin{array}{l}\text { No. of } \\
\text { experts }\end{array}$ & $\%$ & \\
\hline 1. Plausibility of the clinical case & - & - & - & - & 3 & 60 & 0.6 \\
\hline 2. Realism & - & - & 2 & 40 & 3 & 60 & 0.6 \\
\hline $\begin{array}{l}\text { 3. Adherence to the available } \\
\text { scientific evidence }\end{array}$ & - & - & 2 & 40 & 3 & 60 & 0.6 \\
\hline $\begin{array}{l}\text { 4. Complexity of the student's level } \\
\text { of knowledge and skills }\end{array}$ & - & - & - & - & 5 & 100 & 1.0 \\
\hline 5. Case summary & - & - & - & - & 5 & 100 & 1.0 \\
\hline $\begin{array}{l}\text { 6. Simulation objectives provided to } \\
\text { the student }\end{array}$ & - & - & - & - & 5 & 100 & 1.0 \\
\hline $\begin{array}{l}\text { 7. Information provided to the } \\
\text { student before simulation }\end{array}$ & - & - & 1 & 20 & 4 & 80 & 0.8 \\
\hline $\begin{array}{l}\text { 8. Data provided to the student } \\
\text { during simulation }\end{array}$ & - & - & - & - & 5 & 100 & 1.0 \\
\hline $\begin{array}{l}\text { 9. Support provided to the student } \\
\text { during simulation }\end{array}$ & & & - & - & 5 & 100 & 1.0 \\
\hline 10. Learning objectives & - & - & - & - & 5 & 100 & 1.0 \\
\hline 11. Promotion of critical thinking & - & - & 1 & 20 & 4 & 80 & 0.8 \\
\hline $\begin{array}{l}\text { 12. Promotion of the ability to } \\
\text { prioritize nursing assessments and } \\
\text { interventions }\end{array}$ & - & - & 1 & 20 & 4 & 80 & 0.8 \\
\hline $\begin{array}{l}\text { 13. Promotion of autonomous } \\
\text { problem solving }\end{array}$ & - & - & 1 & 20 & 3 & 60 & 0.6 \\
\hline 14. Type of simulator & - & - & - & - & 5 & 100 & 1.0 \\
\hline 15. Simulator parameters & - & - & - & - & 4 & 80 & 0.8 \\
\hline 16. Simulated environment & - & - & 1 & 20 & 4 & 80 & 0.8 \\
\hline 17. Available material and equipment & - & - & 2 & 40 & 1 & 20 & 0.4 \\
\hline 18. Questions in the debriefing & - & - & 1 & 20 & 3 & 60 & 0.6 \\
\hline $\begin{array}{l}\text { 19. Reflection on and analysis of the } \\
\text { procedures during the debriefing }\end{array}$ & - & - & - & - & 5 & 100 & 1.0 \\
\hline $\begin{array}{l}\text { 20. Synthesis and feedback given to } \\
\text { the student during the debriefing }\end{array}$ & - & - & 1 & 20 & 4 & 80 & 0.8 \\
\hline Global CVI of the instrument & & & & & & & 0.81 \\
\hline
\end{tabular}

CLINICAL CASE 2 (Early sexual initiation, pregnancy, and abortion)

\begin{tabular}{lccccccc}
\hline \multirow{2}{*}{ Assessed items } & \multicolumn{2}{c}{ Inappropriate } & Partially appropriate & \multicolumn{2}{c}{ Appropriate } \\
\cline { 2 - 8 } & $\begin{array}{l}\text { No. of } \\
\text { experts }\end{array}$ & $\%$ & $\begin{array}{c}\text { No. of } \\
\text { experts }\end{array}$ & $\%$ & $\begin{array}{c}\text { No. of } \\
\text { experts }\end{array}$ & $\%$ & CVI \\
\hline 1. Plausibility of the clinical case & - & - & - & - & 6 & 100 & 1.0 \\
\hline 2. Realism & - & - & 2 & 33.3 & 4 & 66.6 & 0.66 \\
\hline $\begin{array}{l}\text { 3. Adherence to the available } \\
\text { scientific evidence }\end{array}$ & - & - & 1 & 16.6 & 5 & 83.3 & 0.83 \\
\hline
\end{tabular}




\begin{tabular}{|c|c|c|c|c|c|c|c|}
\hline $\begin{array}{l}\text { 4. Complexity of the student's level } \\
\text { of knowledge and skills }\end{array}$ & - & - & 1 & 16.6 & 5 & 83.3 & 0.83 \\
\hline 5. Case summary & - & - & 1 & 16.6 & 5 & 83.3 & 0.83 \\
\hline $\begin{array}{l}\text { 6. Simulation objectives provided to } \\
\text { the student }\end{array}$ & - & - & - & - & 6 & 100 & 1.0 \\
\hline $\begin{array}{l}\text { 7. Information provided to the stu- } \\
\text { dent before simulation }\end{array}$ & - & - & 1 & 33.3 & 4 & 66.6 & 0.66 \\
\hline $\begin{array}{l}\text { 8. Data provided to the student } \\
\text { during simulation }\end{array}$ & - & - & - & - & 6 & 100 & 1.0 \\
\hline $\begin{array}{l}\text { 9. Support provided to the student } \\
\text { during simulation }\end{array}$ & & & - & - & 6 & 100 & 1.0 \\
\hline 10. Learning objectives & - & - & - & - & 6 & 100 & 1.0 \\
\hline 11. Promotion of critical thinking & - & - & 1 & 16.6 & 5 & 83.3 & 0.83 \\
\hline $\begin{array}{l}\text { 12. Promotion of the ability to } \\
\text { prioritize nursing assessments and } \\
\text { interventions }\end{array}$ & - & - & 1 & 16.6 & 5 & 83.3 & 0.83 \\
\hline $\begin{array}{l}\text { 13. Promotion of autonomous } \\
\text { problem solving }\end{array}$ & 1 & 16.6 & 1 & 16.6 & 4 & 66.6 & 0.66 \\
\hline 14. Type of simulator & - & - & - & - & 6 & 100 & 1.0 \\
\hline 15. Simulator parameters & - & - & 2 & 33.3 & 4 & 66.6 & 0.66 \\
\hline 16. Simulated environment & - & - & 4 & 66.6 & 2 & 33.3 & 0.33 \\
\hline 17. Available material and equipment & - & - & 4 & 66.6 & 2 & 33.3 & 0.33 \\
\hline 18. Questions in the debriefing & - & - & - & - & 5 & 83.3 & 0.83 \\
\hline $\begin{array}{l}\text { 19. Reflection on and analysis of the } \\
\text { procedures during the debriefing }\end{array}$ & - & - & - & - & 6 & 100 & 1.0 \\
\hline $\begin{array}{l}\text { 20. Synthesis and feedback given to } \\
\text { the student during the debriefing }\end{array}$ & - & - & - & - & 6 & 100 & 1.0 \\
\hline Global CVI of the instrument & & & & & & & 0.81 \\
\hline
\end{tabular}

In general, regarding both clinical cases, the number of items with a CVI above the acceptance criterion was higher than the number of items with a CVI below the established mean score. Thus, it can be concluded that the instruments developed for the simulation have high reliability to be used in maternal-child nursing education simulations, enabling students to learn how to deliver efficient nursing care (Negri et al., 2017).

The experts also assessed the proposed objectives for each clinical case. They were developed with the purpose of guiding the expert's assessment during the simulated scenario and highlighting the students' expected performance in the high-fidelity maternal-child simulation scenario. Subsequently, the total and the item-level CVIs were 0.81 for both clinical cases.

With regard to clinical case 1 (Table 1 ), the experts suggested the inclusion of the laryngoscope in the list of materials and the specification of the tube size or the inclusion of one of each in the list of materials.

In clinical case 1, as for the students' expected actions, the experts suggested the inclusion of the following items: "request a blood gas test" detailing the blood parameters that may contribute to the patient's diagnosis; "use a room divider" before the physical examination due to the need to investigate signs of sexual abuse; "request a psychologist and social worker"; "assess the patient's verbal and non-verbal communication"; and "post-cardiac arrest care".

The experts suggested that the defibrillator shock dose should be revised because the patient was a 13-year-old adolescent, thus the dose should be the one of an adult depending on the child's size. The dose of adrenaline was 
suggested as an item to be revised according to the same criterion, enabling the possibility of giving the dose for an adult.

With regard to clinical case 2 (Table 2), the experts suggested the inclusion of items in the list of materials: "stretcher for clinical examination", "light", and "gynecological speculum". In relation to the expected actions, the following was recommended: the inclusion of the item "inform the patient about the ethical-professional secrecy"; readapt the item "contact the adolescents' parents/guardians" to "encourage the presence of the parent/guardian in the consultation"; reevaluate the need for the item "perform the pelvic examination" because it is the first contact with the patient.

If the above-mentioned objective is excluded, the items of the materials relating to the gynecological examination will not need to be included. The experts also suggested changing the item "refer to consultation with a gynecologist for exams" to "request the necessary exams" because the primary care nurse can request examinations such as urine and hematology tests, ultrasound, among others, as well as the inclusion of the item "schedule a prenatal consultation".

The experts questioned the amount of information in the description of the clinical cases because they believed that with fewer details the students would be more impelled to further explore the scenario and discover the information by themselves.

However, the experts were explained that the inclusion of details in the case descriptions was intentional because each scenario lasted only 10 minutes and so the most relevant and direct actions were prioritized to achieve the desired outcome, that is, the students' learning. In view of this explanation, the experts understood that it was important to assess those aspects given the short duration of scenarios.

\section{Discussion}

The criteria for development of the scenarios should be based on the expected objectives for each simulation (Góes et al., 2014). To check the reliability for application of the developed cases, they need to be validated by experts (Eduardo et al., 2016; Góes et al., 2014).
Taking into account the suggestions given by the experts for each scenario, as shown in $\mathrm{Ta}$ ble 3, the items with a CVI below 0.75 on individual items were considered of low relevance to the scenarios. This means that these items need to be reformulated and reassessed for a subsequent application of the cases put forward in this study.

In clinical case 1 , debriefing included a discussion between the participants and those responsible for the scenario. In clinical case 2, the experts also participated in this step. The quality of the ideas shared during the discussion improved with the experts' participation because their experience in each clinical case enriched the analysis of the questions raised.

In the final step of the simulated clinical experience (the debriefing), there was a moment of reflection and analysis of the simulation which allowed the students to express their feelings and assess their own performance.

Studies show that, even when the teacher plays the role of facilitator, students are still affected by anxiety and distress. Therefore, debriefing is important to work on these feelings because it promotes the development of competencies and enables a collaborative attitude of those involved in the validation process in the discussion of important points for the improvement of skills, which helps the student to build self-confidence (Fernandes et al., 2016; Souza et al., 2017).

High-fidelity simulation allows students to apprehend the contents taught in the classroom prior to the reproduction of clinical cases. This theory-practice association allows students to understand the actual importance of applying the right techniques of the profession and improving their skills (Costa, Medeiros, Martins, Cossi, \& Araújo, 2017).

In this study, based on the validation of the debriefing, the experts suggested the need to change the expression "negative aspects" to "aspects that can be improved" because students would not feel embarrassed and criticized for not having accomplished an expected outcome in the scenario.

The instruments used to assess students' skills were validated. Based on the expected outcomes for each clinical case, these instruments guide the experts who assess the scenarios, and can contribute to improving the 
assessment tools and the pedagogical practices and performance in clinical practice (Barragán, Hernández, \& Medina, 2017).

Content validity allows improving the formulation of theoretical proposals, ensuring the excellence and accuracy of scenario assessment, and is suitable for indicating the skills and behaviors to be achieved by the students. The above-mentioned experts' suggestions bring the assessment instruments closer to the desired outcomes for the teaching-learning process and this active methodology has many advantages for the students who are at the center of the training process (Barragán et al., 2017).

The discussion of the results achieved in each scenario allows students to become more aware of their learning process and encourage their autonomy and responsibility as future nurses. At this moment, students communicate and exchange ideas with people who share the same experiences and become more used to dealing with teamwork situations, which are essential in health care delivery (Goés et al., 2014).

In this study, scenarios were developed by teachers and students of the undergraduate nursing program, implemented using high-fidelity simulation, and their content was validated by maternal-child health experts who made key suggestions for improving the effectiveness of both scenarios applied in maternal-child nursing education (Eduardo et al., 2016).

Considering that the validation of clinical cases for simulation improves students' self-confidence, the instruments used in both clinical cases meet the purpose of using high-fidelity simulation in education. It is believed that this methodology is an important resource to improve both nursing students' learning and health professionals' technical skills (Góes et al., 2014; Medeiros et al., 2015).

Further studies are needed to assess students' performance in maternal-child simulation and recommend the active teaching methodology by exploring the impact of this methodology on the development of skills and competencies for a safe care delivery to adolescents in the clinical situations described in both clinical cases.

A limitation of this study is the use of voluntary actors (nursing degree students without specific theater training). However, this item was not reported by the experts while assessing the realism of the scenario.

\section{Conclusion}

This study reached the proposed objective, which was to describe the development of two clinical cases and their validation process with the purpose of using them in high-fidelity maternal-child simulation.

The experts' contribution as evaluators, together with the students' experiences in the simulated scenarios, was essential for the validation of the clinical scenarios.

Therefore, the availability of these scenarios and the instruments validated in this study, together with the training of more professionals on this active teaching methodology, will contribute to achieving positive outcomes for a quality high-fidelity simulation in maternal-child education.

Future studies on maternal-child simulation with students from other places and countries should be conducted to confirm the effectiveness of the applicability of these clinical cases in nurses' training, given the lack of studies in this area.

Acknowledgement: To the Federal District Research Support Foundation (FAPDF) for funding this research through notice no. 03/2016. Protocol: 9721.56.32761.05042016

\section{References}

Alexandre, N. M., \& Coluci, M. Z. (2011). Validade de conteúdo nos processos de construçáo e adaptação de instrumentos de medidas. Ciência \& Saúde Coletiva, 16(7), 3061-3068. doi:10.1590/S141381232011000800006

Alconero-Camarero, A. R., Gualdrón-Romero, A., Sarabia-Cobo, C. M., \& Martinez-Arce, A. (2016). Clinical simulation as a learning tool in undergraduate nursing: Validation of a questionnaire. Nurse Education Today, 39(1), 128-134. doi:10.1016/j. nedt.2016.01.027

Almeida, R. G., Mazzo, A., Martins, J. C., Baptista, R. C., Girão, F. B., \& Mendes, I. A. (2015). Validação para a língua portuguesa da escala Student Satisfac- 
tion and Self-Confidence in Learning. Revista Latino-Americana de Enfermagem, 23(6), 1007-1013. doi:10.1590/0104-1169.0472.2643

Balki, M., Hoppe, D., Monks, D., Sharples, L., Cooke, M. E., Tsen, L., \& Windrim, R. (2017). The PETRA (Perinatal Emergency Team Response Assessment) scale: A high-fidelity simulation validation study. Journal of Obstetrics and Gynaecology Canada, 39(7), 523533. doi:10.1016/j.jogc.2016.12.036

Baptista, R. C., Martins, J. C., Pereira, M. F., \& Mazzo, A. (2014). Simulação de alta-fidelidade no curso de enfermagem: Ganhos percebidos pelos estudantes. Revista Enfermagem Referência, 4(1), 135-144. doi:10.12707/RIII13169

Barragán, J., Hernández, N. E., \& Medina, A. (2017). Validación de guías de autoaprendizaje en simulación clínica para estudiantes de enfermería. Revista Cuidarte, 8(2), 1582-1590. doi:10.15649/cuidarte.v8i2.377

Carvalho, E. C., Oliveira-Kumakura, A. R., \& Morais, S. C. (2017). Raciocínio clínico em enfermagem: Estratégias de ensino e instrumentos de avaliação. Revista Brasileira de Enfermagem, 70(3), 662-668. doi:10.1590/0034-7167-2016-0509

Costa, R. R., Medeiros, S. M., Martins, J. C., Cossi, M. S., \& Araújo, M. S. (2017). Percepção de estudantes da graduação em enfermagem sobre a simulação realística. Revista Cuidarte, 8(3), 1799-1808. doi:10.15649/ cuidarte.v8i3.425

Eduardo, A. H., Mendes, A. A., Binotto, C. C., Tognoli, S. H., \& Tucci, A. M. (2016). Cenário para simulação de resíduos de serviços de saúde: Estudo metodológico. Online Brazilian Journal of Nursing, 15(4), 611-616. doi:10.17665/1676-4285.20165672

Fernandes, A. K., Ribeiro, L. M., Brasil, G. C., Magro, M. C., Hermann, P. R., Ponce de Leon, C. G.,Viduedo, A. F. S., \& Funghetto, S. S. (2016). Simulação como estratégia para o aprendizado em pediatria. Revista Mineira de Enfermagem, 20(976), 1-8.

Góes, F. S., Dalri, M. C., Fonseca, L. M., Canini, S. R., \& Scochi, C. G. (2014). Desenvolvimento de casos clínicos para o ensino do raciocínio diagnóstico. Revista Eletrónica de Enfermagem, 16(1), 44-51. doi:10.5216/ ree.v16i1.19812

Instituto Brasileiro de Geografia e Estatística. (2015). Pes- quisa Nacional de Saúde do Escolar: Relatório. Rio de Janeiro, Brasil: Autor.

Medeiros, R. K., Ferreira, J. M., Torres, G. V., Vitor, A. F., Santos, V. E., \& Barichello, E. (2015). Validação de conteúdo de instrumento sobre a habilidade em sondagem nasogástrica. Revista Eletrónica de Enfermagem, 17(2), 278-289. doi:10.5216/ree.v17i2.28820

Merry, A. F., Hannam, J. A., Webster, C. S., Edwards, K., Torrie, J., Frampton, C., ... Weller, J. M. (2017). Retesting the hypothesis of a clinical randomized controlled trial in a simulation environment to validate anesthesia simulation in error research (the VASER Study). Anesthesiology, 3(126), 742-781. doi:10.1097/ ALN.0000000000001514

Negri, E. C., Mazzo, A., Martins, J. C. A., Pereira, J. G. A., Almeida, R. G., \& Pedersoli, C. E. (2017). Simulação clínica com dramatização: Ganhos percebidos por estudantes e profissionais de saúde. Revista Latino-Americana de Enfermagem, 29(5), 489-497. doi:10.1590/1518-8345.1807.2916

Perrin, D., Badel, P., Orgéas, L., Geindreau, C., Aurélien, D., Albertini, J., \& Avril, S. (2015). Patient-specific numerical simulation of stent-graft deployment: Validation on three clinical cases. Journal of Biomechanics, 48(10), 1868-1875. doi:10.1016/j.jbiomech.2015.04.031

Polit, D. F., Beck, C. T. (2011). Fundamentos de pesquisa em enfermagem: Avaliação de evidências para as práticas da enfermagem ( $7 \mathrm{a}$ ed.). Porto Alegre, Brasil: Artmed.

Souza, J. M., Silva, F. R., Oliveira, K. M., Venancio, A. F., Hermann, P. R., \& Magro, M. C. (2017). Debriefing como ferramenta de avaliação qualitativa no ensino simulado. Investigação Qualitativa em Saúde, 1(2), 841-848. Retrieved from https://proceedings.ciaiq. org/index.php/ciaiq2017/article/view/1281/1241

Sarfati, L., Ranchon, F., Vantard, N., Schwiertz, V., Larbre, V., Parat, S., Faudel, A., \& Rioufol, C. (2018) Human-simulation-based learning to prevent medication error: A systematic review. Journal of Evaluation of Clinical Practice, 31(1), 1-10. doi:10.1111/jep.12883

Tjoflat, I., Vaga, B. B., \& Soreide, E. (2017). Implementing simulation in a nursing education programme: $\mathrm{A}$ case report from Tanzania. Advances in Simulation, 2(17), 1-4. doi:10.1186/s41077-017-0048-z 
